\title{
PENGARUH PEMBIAYAAN DEFISIT ANGGARAN TERHADAP INFLASI DAN PERTUMBUHAN EKONOMI: SUATU SIMULASI MODEL EKONOMI MAKRO INDONESIA 1970 - 2003
}

\author{
Joko Waluyo \\ Univesitas Pembangunan Nasional "Veteran" Yogyakarta
}

\begin{abstract}
The objective of this research is to identify the impact of budget deficit financing on inflation and economic growth. Simulation are conducted using the small open macroeconomics model specified by Waluyo (2005) with 10.000 replication on the stochastic simulation. Using the secondary data of the Indonesian economy from 1970 to 2003, simulation results show that budget deficit financing from foreign debt and monetary policies would increase the economic growth, but inflationary. On the other hand, tax effort policies are considered to be better, since simulation results show that they would improve economic growth without being inflationary.
\end{abstract}

Keywords: budget deficit, macroeconomic model, economic growth, simulation

\section{PENDAHULUAN}

Di Indonesia, isu defisit anggaran mendapatkan perhatian yang utama, bahkan sejak Kabinet Ampera (kabinet Orba pertama). Perhatian ini disebabkan oleh tingginya tingkat inflasi yang disebabkan oleh pembiayaan defisit anggaran dengan pencetakan uang. Pengalaman ini membuat pemerintah mengintroduksi anggaran yang berimbang dan dinamis untuk menggantikan anggaran moneter. Di mana anggaran dibuat dengan tujuan untuk "menertibkan" defisit anggaran dengan dibiaya dari utang luar negeri (Seda, 2003: 68). Dengan memasukkan utang luar negeri sebagai sumber penerimaan negara maka anggaran terlihat sebagai balance budget. Utang luar negeri ini bukannya tanpa masalah, beban utang luar negeri yang semakin membengkak membawa konsekuensi logis membebani anggaran dengan pembayaran pokok dan bunga utang yang juga ikut meningkatPT.

Idealnya semua pengeluaran pemerintah dibiayai oleh penerimaan pajak. Peningkatan penerimaan pajak akan menaikkan total penerimaan pemerintah. sehingga defisit akan berkurang. Defisit anggaran pemerintah pusat Indonesia dibiayai dengan: Utang luar negeri, Pembiayaan dalam negeri melalui sektor perbankan maupun non perbankanTPT. Pembiayaan melalui sektor perbankan dapat melalui bank sentral dan bank umum. Defisit anggaran yang melalui sektor perbankan dapat ditelusuri melalui neraca otoritas moneter dan neraca konsolidasi bank umum yang berupa perubahan net claim central government (NCG). Pembiayaan melalui sistem non perbankan berupa penerbitan obligasi negara dan privatisasi aset negara, terutama aset negara yang dikelola BPPN. Utang ke luar negeri merupakan alternatif pembiayaan yang paling dominan selama tahun 1969-2000, sedang antara tahun 2001-2003 pembiayaan dalam negeri lebih dominan

Pengaruh defisit anggaran terhadap variabel ekonomi makro sangat tergantung oleh mekanisme pembiayaan defisit yang digunakan (Saleh, 2003 dan 2004). Hampir semua mekanisme pembiyaaan defisit anggaran akan berpengaruh terhadap pertumbuhan ekonomi. Hal 
ini terjadi karena peningkatan penerimaan akan memberikan keleluasaan untuk menaikkan pengeluaran pemerintah sehingga pertumbuhan ekonomi akan ikut naik. Jika utang yang digunakan untuk pembiayaan defisit digunakan untuk investasi pemerintah maka akan berpengaruh lebih besar terhadap perekonomian dan penyerapan tenaga kerja, daripada digunakan untuk membiayai konsumsi pemerintah. Pembiayaan melalu sektor perbankan akan berpengaruh terhadap inflasi dan selanjutnya akan mempengaruhi pertumbuhan ekonomi riil (Chantrasmi, 1999).

Pembiayaan defisit anggaran dengan menggunakan utang luar negeri dilatarbelakangi oleh trauma inflasi yang tinggi pada tahun 1960-an, yang disebabkan oleh pembiayaan defisit anggaran dengan pencetakan uang. APBN yang berimbang sangat ampuh sebagai pengendali inflasi jika defisit anggaran ditutup dengan penambahan stok jumlah uang beredar. Defisit dalam negeri (dalam rupiah) akan didanai oleh utang luar negeri (dalam mata uang asing). Pertukaran ini akan menambah stok jumlah uang yang beredar, karena devisa tadi dibeli oleh Bank Indonesia dan komersial dengan menciptakan uang giral. Jika semua surplus devisa dibeli oleh Bank Indonesia maka akan terjadi monetization, sehingga menyebabkan pertambahan stok uang beredar yang sangat cepat. Hal ini semakin mempersulit Bank Indonesia untuk mengendalikan inflasi dan kestabilan nilai tukar rupiah (Nasution, 1984a dan Nasution, 1984b). Pada sisi yang lain utang luar negeri akan menambah capital inflow pada saat penarikan utang baru, tetapi akan menambah capital outflow pada saat membayar bunga dan cicilan utang.

Jika defisit anggaran dibiayai dengan penerbitan obligasi negara maka permintaan kredit pemerintah mengalami kenaikan, sehingga tingkat suku bunga di pasar modal akan meningkat. Kenaikan tingkat bunga obligasi negara menyebabkan biaya investasi terasa mahal, sehingga akan meng-crowd out investasi swasta (Hossain Akhtar et al., 1998). Penerbitan obligasi negara dalam jumlah besar di dalam pasar modal dan pasar uang yang belum berkembang akan memberikan tekanan yang kuat terhadap anggaran dan mendesak keluar (crowd out) pasar keuangan. Hubungan antara pembiayaan defisit anggaran dengan variabel ekonomi makro terjadi sebuah sistem simultan, sehingga perlu dilakukan sebuah simulasi dari model ekonomi makro yang mengadopsi pembiayaan defisit anggaran pemerintah. Permasalahan ini merupakan pokok bahasan utama dalam penelitian ini.

\section{TINJAUAN LITERATUR}

\subsection{Definisi dan Pengukuran Defisit}

Secara akuntansi, anggaran pemerintah terlihat bahwa penerimaan akan sama dengan pengeluaran, sehingga anggaran akan selalu terlihat dalam kondisi yang seimbang. Terjadinya defisit atau surplus anggaran ditandai dengan adanya item-item penyeimbang (balancing items) baik dalam penerimaan maupun pengeluaran, sehingga akan terlihat terjadinya ketidakseimbangan antara pengeluaran dan penerimaan. Hubungan antara defisit dan pembiayaan anggaran dapat dilihat dengan menyusun sebuah kendala anggaran pemerintah (government budget constraint). Secara sederhana kendala anggaran pemerintah satu periode dapat dituliskan sebagai berikut (Agenor, 1999: 91):

$$
G-\left(T_{t}+T_{n}\right)+i B_{-1}+i^{*} E B_{g-1}=\Delta L^{g}+\Delta B+E \Delta B_{g}^{*}
$$

Di mana $G$ adalah pengeluaran pemerintah untuk pembelian barang dan jasa (termasuk juga current dan capital expenditure). $\mathrm{T}_{\mathrm{t}}$ adalah penerimaan pajak (net of transfer payment) dan $\mathrm{T}_{\mathrm{n}}$ adalah penerimaaan bukan pajak. B adalah beban stok utang dalam negeri pemerintah pada akhir tahun, termasuk juga beban suku bunga yang ditentukan di pasar (i). $B_{g}^{*}$ adalah beban stok utang luar negeri yang dinyatakan dalam valuta asing $(E)$, termasuk juga beban suku bunga utang luar negeri $\left(i^{*}\right)$. E adalah nilai tukar nominal. $L^{g}$ adalah nilai stok kredit nominal yang dialokasikan oleh bank sentral. Sisi kiri persamaan (1) menunjukkan besarnya defisit anggaran pemerintah yang 
dipengaruhi oleh pengeluaran pemerintah, pembayaran bunga utang, dan penerimaan pajak dan non pajak bersih. Sedangkan sisi kanan persamaan menunjukkan mekanisme pembiayaan defisit anggaran pemerintah yaitu dengan utang terhadap bank sentral (pencetakan uang), utang ke dalam negeri dan utang ke luar negeri. Dengan asumsi pemerintah tidak perlu membayar bunga utang ke bank sentral.

Berbagai konsep pengukuran defisit anggaran sangat tergantung dengan kriteria yang digunakan dan tujuan analisis. Biasanya pilihan konsep defisit yang tepat tergantung oleh beberapa faktor, antara lain: jenis ketidakseimbangan yang terjadi, cakupan pemerintah (pemerintah pusat, konsolidasi pemerintah, dan sektor publik), metode akuntasi (cash dan accrual basis), dan status dari contingent liabilities (Simanjuntak, 2001). Beberapa konsep ukuran defisit anggaran yang banyak digunakan, antara lain: conventional defisit, current fiscal defisit, primary defisit, monetary defisit dan operational defisit (Booth dan Mc Cawley, 1985; Gunawan, 1991; Blejer dan Cheasty, 1991 dan 1992; serta Buiter, 1982 dan 1995) seperti terlihat dalam Tabel 1.

Tabel 1

Ringkasan Metode Perhitungan Defisit/Surplus Anggaran

\begin{tabular}{|c|c|c|}
\hline No & Jenis Defisit & Metode \\
\hline 1. & $\begin{array}{l}\text { Defisit Konvensional dan } \\
\text { Defisit Keseluruhan }\end{array}$ & $\begin{array}{l}\text { a) } D E F=(R+A)-(G+B) \text {; atau } \\
\text { b) } D E F=(R+A+D)-(G+B) \text {; atau } \\
\text { b) } D E F=(R-A)-T X_{r} ; \text { atau } \\
\text { c) } D E F=(R-A)-G\end{array}$ \\
\hline $\begin{array}{l}2 . \\
3 . \\
4 . \\
5 .\end{array}$ & $\begin{array}{l}\text { Defisit Fiskal Berjalan dan } \\
\text { Konsep Nilai Bersih } \\
\text { Defisit Domestik } \\
\text { Defisit Moneter } \\
\text { Defisit Primer }\end{array}$ & $\begin{array}{l}D E F=S g=R d-G_{r} \\
D E F=R d-G d \\
D_{b}=R-\left(G-\left(D_{f}+D_{n b}\right)\right) \\
D E F=(R-A)-(G-B)\end{array}$ \\
\hline 6. & Augmented Defisit Primer & $\mathrm{DEF}=\{(\mathrm{R}-\mathrm{A})-(\mathrm{G}-\mathrm{B})\}-\frac{\left[i_{t}^{*}\left(1+\varepsilon_{t}\right)+\varepsilon_{t}-i_{t}\right]}{\left(1+\pi_{t}\right)\left(1+g_{t}\right)}\left(\mathrm{D}_{\mathrm{t}-1}-\mathrm{FR} \mathrm{R}_{\mathrm{t}-1}\right)+\mathrm{S}$ \\
\hline 7. & Defisit Operasional & $\begin{array}{l}\text { a) } D E F=((R-A)-G)-i B ; \text { atau } \\
\text { b) } D E F=((R-A)-(G-B))+i B \\
\text { Surplus/Defisit Primer: }\end{array}$ \\
\hline 8. & Defisit APBN Indonesia & $\begin{array}{l}\overline{D E F}=(R+A)-(G-B) \\
\text { Defisit Anggaran: }\end{array}$ \\
\hline & & $\mathrm{DEF}=(\mathrm{R}+\mathrm{A})-\mathrm{G}$ \\
\hline
\end{tabular}

Keterangan : Jika nilai sisi kiri persamaan (-) maka menunjukkan terjadinya defisit anggaran, dan berlaku sebaliknya. Di mana:

$-\mathrm{DEF}=$ Defisit Anggaran. $\quad-\mathrm{S}_{g} \quad=$ Tabungan Pemerintah.

$-\mathrm{R} \quad=$ Total Penerimaan Pemerintah. $\quad-R_{d}=$ Penerimaan Dalam Negeri.

$-A \quad=$ Total Hibah. $\quad-G_{r} \quad=$ Pengeluaran Rutin $(D N+L N)$.

$-\mathrm{G}=$ Total Pengeluaran Pemerintah. $-\mathrm{B}=$ Pembayaran Bunga Utang.

$-\mathrm{D}=$ Total Utang Pemerintah. $\quad-\mathrm{Gd}=$ Pengeluaran Dalam Negeri.

$-D_{f} \quad=$ Utang LN Pemerintah. $\quad-F R \quad=$ Cadangan Devisa Luar Negeri.

$-D_{b}=$ Utang dari Sektor Perbankan. $\quad-S=$ Seignorage.

$-D_{\mathrm{nb}}=$ Utang DN dari Non Perbankan. $\quad-\mathrm{TX}_{\mathrm{r}} \quad=$ Penerimaan Pajak.

$-i \quad=$ Suku Bunga Riil. $\quad-\pi \quad=$ Tingkat Inflasi.

$-\varepsilon \quad=$ Nilai Tukar. $\quad-g \quad=$ Pertumbuhan Ekonomi.

$-\mathrm{i}^{\star} \quad$ = Suku Bunga Utang Luar Negeri. 


\subsection{Mekanisme Pembiayaan Defisit Anggaran}

Defisit anggaran pemerintah yang terjadi harus dibiayai dengan sumber-sumber yang mungkin dilakukan oleh pemerintah. Pembiayaan defisit anggaran seharusnya untuk mendanai pengeluaran pemerintah yang dapat meningkatkan produktivitas perekonomian, yaitu pengeluaran kapital pemerintah untuk investasi. Sumber pembiayaan defisit anggaran secara konvensional terdiri dari money financed dan bond financed defisit, yaitu pembiayaan dengan pencetakan uang dan pembiayaan dengan menerbitkan bonds atau obligasi negara (Turnovsky dan Wohar, 1987; dan Scarth, 1996). Menurut Garcia (1996) Secara garis besar ada dua cara pembiayaan defisit yaitu dengan pencetakan uang (money creation) dan utang (Debt). Buiter (1982 dan 1995) mengidentikasi sumber pembiayaan defisit berasal dari:Utang luar negeri, Utang dalam negeri, Pencetakan uang, Privatisasi, dan Running down cadangan devisa pemerintah. Masing-masing mekanisme pembiayaan defisit memberikan pengaruh yang berbeda terhadap perekonomian baik sendiri-sendiri maupun secara bersama-sama.

Mekanisme pembiayaan yang pertama yaitu pencetakan uang. Pencetakan uang baru akan memberikan penerimaan kepada pemerintah karena adanya selisih nilai nominal dan nilai riil dari uang, seignorage. Mekanisme pembiayaan ini mempunyai keterbatasan, karena penambahan uang beredar yang terlalu besar akan menyebabkan terjadinya inflasi dan merupakan suatu bentuk pajak bagi pemegang cash balance (inflation tax). Di negara-negara sedang berkembang yang memiliki masalah keseimbangan internal biasanya pencetakan uang sebagi sumber utama inflasi. Sehingga kebijakan fiskal disarankan untuk mengendalikan defisit anggaran sedangkan kebijakan moneter membiayai defisit dengan kebijakan pasif (Gunardi, 2000: 17-18). Hal ini menuntut kebijakan moneter yang lebih independen.

Mekanisme pembiayaan yang kedua yaitu dengan mêlakukan utang ke luar negeri. Utang luar negeri dapat digunakan sebagai sumber pembiayaan defisit anggaran dengan catatan tidak berlaku secara permanen. Pemerintah untuk mendapatkan utang luar negeri harus mampu meyakinkan debitur luar negeri bahwa perekonomian mampu menampilkan creditworthy yang meyakinkan. Utang luar negeri sebagai sumber pembiayaan anggaran memiliki beberapa keterbatasan antara lain: adanya beban pengembalian di masa depan sehingga pemerintah dituntut untuk mengalokasikan utang guna mendanai proyek-proyek yang produktif, adanya unsur spekulatif terhadap nilai tukar apabila tidak ada kontrol devisa yang kuat, menyebabkan pengaruh inflationary jika tidak ada tindakan sterilisasi terhadap utang luar negeri.

Mekanisme yang ketiga yaitu dengan melakukan utang ke dalam negeri atau penerbitan obligasi negara. Kebijakan ini mensyaratkan suatu pasar modal yang baik dan adanya kemungkinan berkembanganya secondary market untuk pasar obligasi negara yang diterbitkan. Kendala yang dihadapi dengan penerbitan obligasi negara yaitu kemungkinan terjadainya fenomena crowding out effect terhadap investasi swasta. Penerbitan obligasi negara untuk pembiayaan defisit akan berakibat terhadap semakin berkurangnya share untuk sektor swasta. Penerbitan obligasi negara akan mengurangi harga obligasi negara itu sendiri dan meningkatkan suku bunga, sehingga akan mematahkan permintaan potensial investasi swasta.

\subsection{Pengaruh Defisit Anggaran terhadap Suku Bunga: Pandangan Klasik, Keynesian, dan Ricardian}

Idealnya pemerintah membiayai anggarannya dengan menggunakan instrumen perpajakan. Sehingga total pengeluaran pemerintah akan sama dengan penerimaan pajak. Kondisi ini sulit untuk diwujudkan dalam dunia nyata, terutama untuk negara-negara yang sedang berkembang karena basis pajaknya sangat terbatas. Alternatif pembiayaan yang sering dilakukan yaitu dengan melakukan pinjaman ke luar negeri untuk negara-negara yang sedang berkembang dan meminjam ke dalam negeri bagi negara-negara maju. Bagian ini akan membahas tentang tiga aliran pemikiran yaitu: Klasik, Keynesian dan Ricardian (Elmendorf et al., 1998). 
Pengaruh Pembiayaan Defisit Anggaran terhadap Inflasi dan Pertumbuhan Ekonomi (Joko Waluyo)

Aliran pemikiran klasik berpandangan bahwa kenaikan pembiayaan defisit anggaran atau pengurangan pajak (tax cut) akan berpengaruh terhadap meningkatnya disposable income (pendapatan yang siap dibelanjakan). Naiknya disposable income menyebabkan konsumen akan membelanjakan untuk barang dan jasa yang lebih banyak. Penambahan kekayaan yang positip berpengaruh terhadap penambahan permintaan agregat. Dalam jangka pendek: kenaikan pinjaman di pasar modal oleh pemerintah hanya bersifat kompensasi parsial terhadap adanya tambahan tabungan. Kenaikan suku bunga dibutuhkan untuk memulihkan keseimbangan yang disebabkan oleh kenaikan tabungan dan berkurangnya konsumsi dan permintaan investasi. Dalam jangka panjang: berkurangnya investasi akan menyebabkan stok kapital menjadi kecil, dan selanjutnya akan membuat pertumbuhan ekonomi menjadi lebih kecil.

Keynesian berpandangan bahwa kenaikan permintaan agregat akan berpengaruh terhadap akumulasi kapital dan output agregat. Pemotongan pajak menyebabkan kenaikan permintaan agregat. Hal ini disebabkan oleh sticky wages, sticky prices atau kekeliruan persepsi temporer. Perubahan dalam permintaan agregat akan berpengaruh terhadap pemanfaatan (utilization) faktor produksi. Keynesian berpendapat bahwa kebijakan anggaran defisit akan berpengaruh terhadap pendapatan nasional hanya melalui perubahan penawaran faktor produksi (Elmendorf et al., 1998).

Pengaruh defisit anggaran terhadap suku bunga dalam pandangan konvensional sebagai berikut: jika pemerintah melakukan pemotongan pajak yang disertai oleh penerbitan obligasi baru (berarti utang negara meningkat). Obligasi negara yang telah jatuh tempo harus tetap dibayar ditambah dengan beban coupon. Jika pemerintah lebih memilih membiayai pengeluarannya dengan penerbitan obligasi baru daripada peningkatan pajak maka akan berpengaruh terhadap peningkatan tingkat suku bunga. Dalam kondisi yang lain ketika tingkat pajak mengalami kenaikan dan tidak berpengaruh terhadap pengeluaran pemerintah dan investasi maka permintaan dana pinjaman (Ioanable funds) akan menurun

Ricardian Equivalence Hypothesis (REH) berpendapat bahwa beberapa kebijakan pemerintah tidak akan membawa pengaruh yang penting bagi perekonomian, neutrality preposition. REH mengkombinasikan dua pendekatan yang fundamental yaitu: kendala anggaran pemerintah dan Permanent Income Hypothesis (PIH). Kendala anggaran pemerintah menyatakan apabila pengeluaran pemerintah tidak mengalami perubahan maka tingkat pajak yang rendah sekarang akan diimbangi oleh kenaikan tingkat pajak dikemudian hari. PIH menyatakan bahwa rumah tangga akan mendasarkan keputusan konsumsinya berdasarkan permanent income, yang besarnya sangat tergantung oleh nilai sekarang pendapatan setelah pajak. Pembiayaan defisit anggaran dengan memotong pajak sekarang akan mempengaruhi beban pajak dikemudian hari, tetapi tidak dalam nilai sekarang, sehingga pemotongan pajak tidak akan mengubah permanent income atau konsumsi (Elmendorf et al., 1998).

\subsection{Tinjauan Penelitian Terdahulu.}

Studi empiris tentang defisit anggaran telah banyak dilakukan diberbagai negara termasuk Indonesia. Pendefinisian defisit anggaran tergantung dengan tujuan studi. Penyusunan persamaan keseimbangan fiskal dalam model ekonometrika biasanya dihubungkan dengan sebuah persamaan kendala anggaran pemerintah, sehingga akan jelas terlihat besarnya defisit anggaran dan alternatif pembiayaannya. Selanjutnya dilakukan identifikasi terhadap hubungan pembiayaan defisit terhadap variabel ekonomi makro (inflasi, suku bunga, pertumbuhan ekonomi, dan lainlain). Beberapa penelitian tentang defisit anggaran dapat diringkas dalam tabel 2.

\section{METODA PENELITIAN}

Rumusan masalah akan dijawab dengan melakukan simulasi model ekonomi makro pembiayaan defisit anggaran yang telah dispesifikasikan oleh Waluyo (2005). Model Waluyo (2005) mengadopsi model yang telah ada yaitu: Model Chantrasmi (1990), Model Tokunaga (1997), Model Soelistyo et al. (1998), Model Joseph et al. (1999), Model Gunardi (2000), Model 
Choeryanto (2003), dan Model Saleh (2004). Model yang digunakan bersifat small open macroeconomic model yang menitikberatkan pada sisi keuangan negara. Model yang dispesifikasikan dalam kerangka keseimbangan agregate demand dan agregate supply.

Secara lengkap model terdiri dari: 6 blok dengan 37 persamaan, 17 persamaan perilaku, dan 18 persamaan identitas, dengan 2 persamaan identitas yang menunjukkan keseimbangan pasar (Keseimbangan permintaan dan penawaran agregat $(Y=Q)$, dan Keseimbangan pasar uang $(M D=M S)$ ). Jumlah variabel endogen sama dengan jumlah persamaan (perilaku dan identitas) maka secara matematis model dapat diestimasi. Struktur masing-masing blok dapat dijelaskan dengan menspesifikasikan persamaan perilaku untuk masing-masing blok sebagai berikut:

1. Blok Produksi

In $Q_{t}=q_{t} f\left(\ln K G_{t}, \ln K P_{t}, \ln L_{t}\right)$

$K G \quad=K G_{t-1}+I G_{t}-\left(0,1839^{*} K G_{t-1}\right)$

$K P_{t} \quad=K P_{t-1}+I P_{t}-\left(0,1839^{*} K P_{t-1}\right)$

Di mana:

$$
\begin{array}{llll}
Q & =\text { Produk Nasional = GDP }(1993=100) & & \mathrm{L}=\text { Tenaga Kerja } \\
\mathrm{KG} & =\text { Kapital Stok Pemerintah } & & \mathrm{IG}=\text { Investasi Pemerintah } \\
\mathrm{KP} & =\text { Kapital Stok Swasta } & \text { IP }=\text { Investasi Swasta }
\end{array}
$$

2. Blok Sektor Riil

$\begin{aligned} \mathrm{CP}_{\mathrm{t}} & =\mathrm{Cp}_{\mathrm{t}} f\left(\left(\mathrm{YD}_{\mathrm{t}}\right), \mathrm{CP}_{\mathrm{t}-1}\right) \\ \mathrm{YD}_{\mathrm{t}} & =\mathrm{Y}_{\mathrm{t}}-\mathrm{TX}_{\mathrm{t}} \\ \mathrm{IP}_{\mathrm{t}} & =\mathrm{ip}_{\mathrm{t}} f\left(\mathrm{Y}_{\mathrm{t}}, \mathrm{i}_{\mathrm{t}}, \mathrm{IP}_{\mathrm{t}-1}\right)\end{aligned}$

Tabel 2

Studi Empiris Tentang Defisit Anggaran

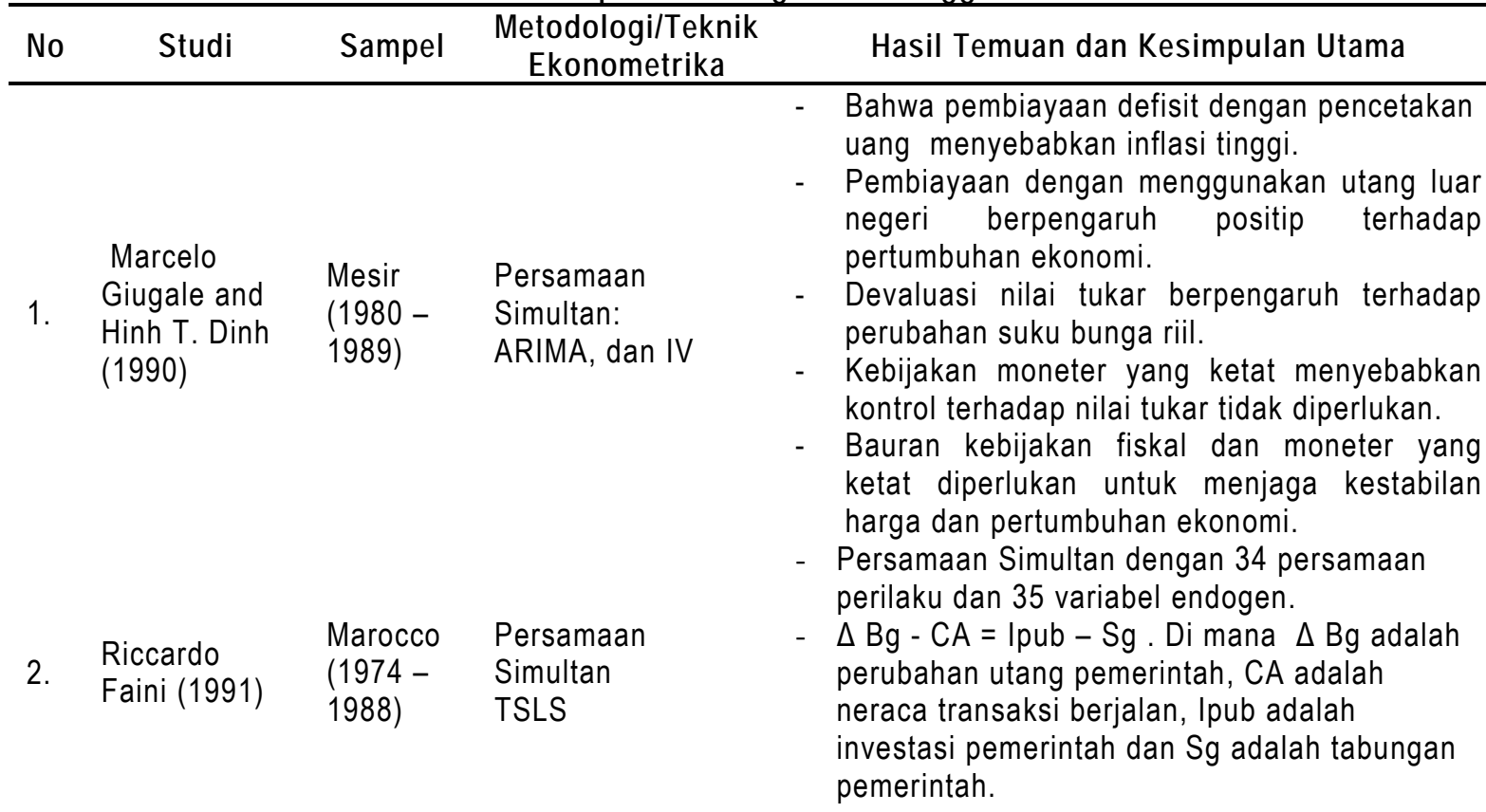


Virabongse Ramangkura,

3. and

Bhanupongse Nindhiprabha, (1970.11987.4)

- Kesimpulan:

- Terjadi peningkatan dalam pembiayaan defisit dengan menggunakan utang luar negeri.

- Pembiayaan dengan operasi moneter tidak memungkinkan, karena menyebabkan inflasi tinggi.

- Hasil simulasi menunjukkan bahwa kenaikan dalam pengeluaran rutin pemerintah akan menyebabkan crowding out pada investasi swasta.

- Kebijakan fiskal ekspansif memungkinkan nilai tukar berpengaruh terhadap credit rationing pada permintaan investasi dengan pengaruh terbatas pada tingkat suku bunga.

- Persamaan Kendala Anggaran: $\mathrm{Dg}=\mathrm{Cg}+\mathrm{lg}-\mathrm{T}$

- Pembiayaan anggaran dinyatakan sebagai variabel eksogen.

- Kesimpulan:

- Kenaikan pajak akan mengurangi defisit anggaran.

- Peranan pajak sebagai stabiliser otomatis meningkat.

- Ketergantungan pada pajak perdagangan internasional meningkat. (1991)

4. A. Gunawan

Indonesia (1991)

$(1969-$ 1992)

\section{OLS}

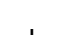

Indonesia (1971.11992.4)
- Model Leiderman Blejer

- Error Correction Model (ECM)

6. Rodzidyanti

Indonesia

- Model Leiderman (1995)

(1969.1-

1993.2

- Granger

Causality

Indonesia Ordinary Least

7. Arti Adji

(1974-

1989)

Square (OLS)
- Hasil simulasi menunjukkan bahwa pembiayaan dengan pencetakan uang akan menyebabkan meningkatnya tagihan pada sektor pemerintah dan meningkatkan uang primer dan uang beredar.

- Defisit domestik, imported inflation, fluktuasi harga migas merupakan penyebab inflasi yang utama di Indonesia.

- Bahwa preposisi Ricardian Equivalence Hypothesis merupakan good approximation untuk studi tentang pengaruh utang antar generasi.

- Pembiayaan defisit APBN tidak berpengaruh terhadap keputusan agen dalam mengatur konsumsinya.

- Saran: Penerbitan obligasi sebagai alternatif pembiayaan defisit

- Dengan Ricardian Equivalence Hypothesis maka pembiayaan anggaran pemerintah adalah netral terhadap perekonomian.

- Adanya transfer antar generasi dari orang tua kepada keturunanannya.

- Tidak terdapat liquidity constraint pada masyarakat Indonesia.

- - Asumsi: Finite horizon.

- Defisit APBN tidak berpengaruh terhadap tingkat suku bunga riil.

- Defisit APBN tidak menyebabkan terjadinya crowding out effect.

- Saran: Mencari sumber pembiayaan lewat: 
KINERJA, Volume 10, No.1, Th. 2006: Hal. 1-22

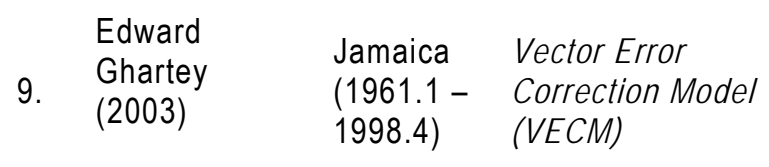

peningkatan perpajakan dan pinjaman ke dalam negeri (penerbitan obligasi).

- Pembiayaan defisit yang dibiayai dengan utang luar negeri menyebabkan inflasi.

- Simulasi model menunjukkan instrumen perpajakan merupakan kebijakan terbaik, karena mampu menjamin kesinambungan fiskal pemerintah.

- Semua variabel stationer dengan menggunakan uji ADF dan PP.

- Suku bunga dan defisit anggaran sebagai variabel endogen

- Suku bunga merupakan sumber utama kenaikan uang primer

- Pertumbuhan ekonomi dan kredit mengurangi defisit, tetapi berpengaruh kecil terhadap pertumbuhan ekonomi.

- Kenaikan pengeluaran pemerintah berpengaruh contractionary dan bukan inflationary.

\footnotetext{
Keterangan: Penelitian tentang studi literatur defisit anggaran yang lebih komprehensif dapat dibaca pada: Ali Salman Saleh, 2004, Public Sector Defisit s and Macroeconomics Performance in Lebanon, Ph.D Dissertation, University of Wollongong Australia, terutama bab 4 dan ibid. The Budget Defisit and Economic Performance: A Survey. University of Wollongong Economics Working Paper Series, September 2003.
}

Di mana:

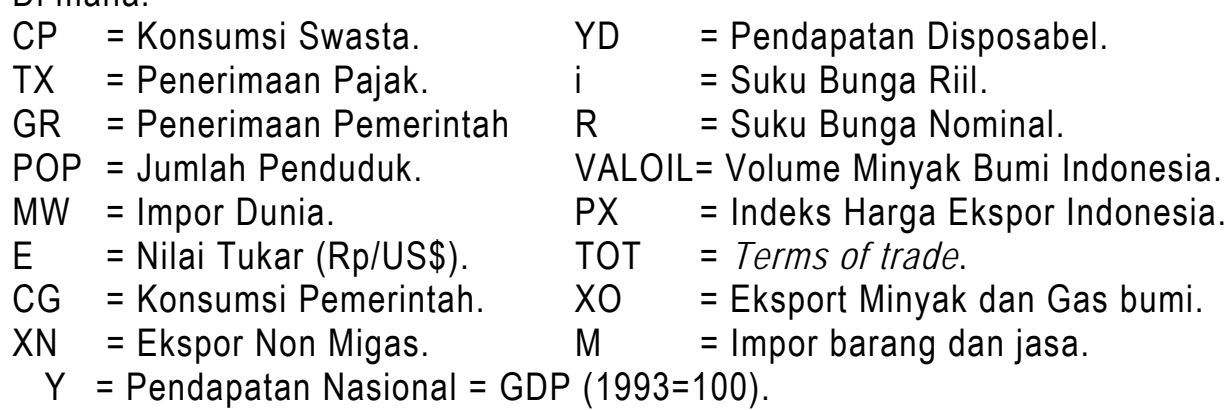

3. Blok Sektor Pemerintah

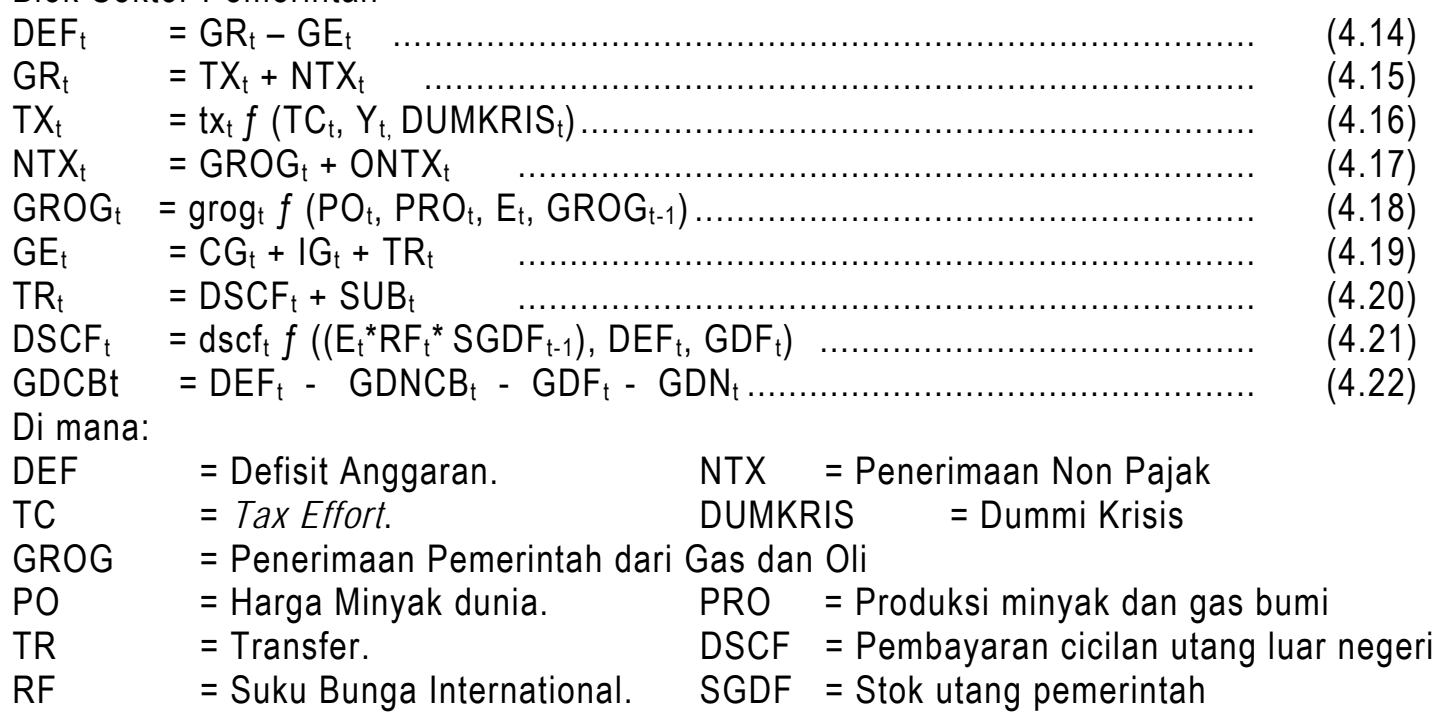




$$
\begin{array}{ll}
\text { GDF } & =\text { Utang Pemerintah. } \quad \text { GDN = Utang dalam negeri pemerintah } \\
\text { GDCB } & =\text { Pembiayaan Defisit Anggaran Melalui Bank Central } \\
\text { GDNCB } & =\text { Pembiayaan Defisit Anggaran Melalui Bank Umum. }
\end{array}
$$

4. Blok Sektor Moneter

$M_{t}=M M_{t} \cdot M B_{t}$

$\mathrm{MM}_{\mathrm{t}}=\mathrm{mm}_{\mathrm{t}} f\left(\mathrm{dYD}_{\mathrm{t}}, \mathrm{RR}_{\mathrm{t}}, \mathrm{R}_{\mathrm{t}}, \mathrm{GDNCB}_{\mathrm{t}}\right)$

$M B_{t}=\left(F R_{t}{ }^{*} E_{t}\right)+D C$

$\mathrm{FR}_{\mathrm{t}} \quad=\mathrm{dFR} \mathrm{R}_{\mathrm{r}}+\mathrm{FR}_{\mathrm{t}-1}$

$\mathrm{DC}_{\mathrm{t}} \quad=\mathrm{GDCB}_{\mathrm{t}}+\mathrm{RBC}_{\mathrm{t}}$

$\mathrm{RBC}_{\mathrm{t}}=\operatorname{rbc}_{\mathrm{t}} f\left(\mathrm{i}_{\mathrm{t}}, \mathrm{E}_{\mathrm{t}}, \mathrm{RR}_{\mathrm{t}}, \mathrm{dPD_{ \textrm {t } }}\right)$

$M D \quad=\operatorname{md} f\left(\mathrm{Y}_{\mathrm{t}}, \mathrm{i}_{\mathrm{t}}\right)$

MS $\quad=M D$

$\mathrm{R}_{\mathrm{t}} \quad=\mathrm{R}_{\mathrm{t}} f\left(\mathrm{Y}, \mathrm{E}_{\mathrm{t}}, \mathrm{MS}_{\mathrm{t}}, \mathrm{PON}_{\mathrm{t}}\right)$

$\mathrm{i}_{\mathrm{t}} \quad=\mathrm{R}_{\mathrm{t}}-\mathrm{dPD} \mathrm{D}_{\mathrm{t}}$

Di mana:

$\begin{array}{llll}\text { MS } & =\text { Penawaran Uang } & \text { MM } & =\text { Angka Pengganda Uang } \\ \text { MB } & =\text { Uang Primer. } & \text { FR } & =\text { Cadangan Devisa } \\ \text { dYD } & =\text { Perubahan Pendapatan Disposabel. } & \\ \text { DC } & \text { = Kredit Domestik. } & \text { RBC } & =\text { Cadangan kredit Bank Central } \\ \text { dpd } & =\text { Inflasi. } & \text { MD } & =\text { Permintaan Uang } \\ \text { PON } & =\text { Harga Obligasi Pemerintah. } & \text { RR } & =\text { Cadangan Minimum }\end{array}$

5. Blok Harga

$\mathrm{dPD}_{\mathrm{t}} \quad=\operatorname{dpd} f\left(\mathrm{dY}_{\mathrm{t}}, \mathrm{dMS}_{\mathrm{t}}, \mathrm{dPDF}_{\mathrm{t}}, \mathrm{dPD}_{\mathrm{t}-1}\right)$

$\mathrm{d}=$ Persentase Perubahan. PDF = Inflasi luar negeri

6. Blok Neraca Pembayaran

$$
\begin{aligned}
& \mathrm{CRA}_{\mathrm{t}}=\left(\left(\mathrm{XO}_{\mathrm{t}}+\mathrm{XN} \mathrm{N}_{\mathrm{t}}\right)^{*}\left(1 / \mathrm{E}_{\mathrm{t}}\right)\right)-\left(\mathrm{M}_{\mathrm{t}}^{*}\left(1 / \mathrm{E}_{\mathrm{t}}\right)\right)+\mathrm{DSCF}_{\mathrm{t}} \\
& C P A_{t}=\left(\mathrm{GDF}_{t}-\left(\mathrm{DSF}_{\mathrm{t}}\right)\right)+\left(\mathrm{PNCl}_{\mathrm{t}}\right) \\
& \mathrm{dFR}_{\mathrm{t}}=\mathrm{CRA}_{\mathrm{t}}+\mathrm{CPA}_{\mathrm{t}} \\
& \mathrm{E}_{\mathrm{t}} \quad=\mathrm{e}_{\mathrm{t}} f\left(\mathrm{DC}_{\mathrm{t}}, \mathrm{FR}_{\mathrm{t}}, \mathrm{Y}_{\mathrm{t}, \mathrm{i}}, \mathrm{dPD_{ \textrm {t } }}\right) \\
& \text { Di mana: } \\
& \text { CRA = Neraca Transaksi Berjalan } \quad \text { CPA = Neraca Modal } \\
& \mathrm{PNCl} \quad=\text { Aliran Modal Masuk Swasta Bersih. } \\
& \text { DSF } \quad=\text { Pembayaran Cicilan Pokok utang Luar Negeri. }
\end{aligned}
$$

Data yang digunakan adalah data sekunder yang berasal dari Statistik Indonesia (Biro Pusat Statitik), Statistik Ekonomi dan Keuangan Indonesia (Bank Indonesia), Nota Keuangan dan RAPBN (Departemen Keuangan), International Finance Statistik Year Books (International Monetary Fund). Dalam penelitian ini digunakan data kapital stok yang telah diestimasi oleh Wicaksono et al. (2002 dan 2003) dan Yudanto et al. (2004). Perbedaan antara tahun fiskal (AprilMaret) dengan tahun kalender (Januari-Desember) pada sebagian besar tahun penelitian mengharuskan peneliti melakukan interpolasi linear. Besarnya pembiayaan melalui sektor perbankan berasal dari NCG pada neraca otoritas moneter dan neraca konsolidasi bank umum seperti yang disarankan oleh Booth dan McCawley (1981), dan Gunardi (2000).

Data pembiayaan dari luar negeri (utang pemerintah netto) berasal dari neraca pembayaran yang dinyatakan dalam US\$. Data investasi dan konsumsi sektor pemerintah (CG dan IG) yang merupakan besarnya jumlah pengeluaran pemerintah setelah ditambah pembayaran transfer (subsidi dan pembayaran cicilan pokok dan bunga utang) tidak tersedia dengan mudah. Konsumsi pemerintah (CG) digunakan proksi variabel dengan menjumlahkan: belanja pegawai dan barang dalam negeri dan luar negeri, dana alokasi umum (DAU), dana otonomi khusus dan 
penyeimbang, dan pengeluaran rutin lainnya. Investasi pemerintah (IG) diproksi dengan menggunakan pejumlahan: pembiayaan dalam rupiah, bantuan proyek, dana bagi hasil, dan dana alokasi khusus (DAK). Sedangkan pembayaran transfer terdiri dari pembayaran bunga utang dalam negeri/luar negeri dan subsidi (migas dan non migas). Permasalahan utama yang terjadi dengan pengklasifikasian seperti ini adalah tidak adanya jaminan bahwa investasi pemerintah (IG) terbebas dari penggunaan untuk konsumsi, begitu juga sebaliknya.

Untuk kepentingan simulasi maka perlu ditentukan variabel kebijakan dan variabel target. Variabel target dapat diklasifikasikan sebagai berikut: Satu: Alternatif kebijakan pembiayaan defisit, terdiri dari: 1) Kenaikan penarikan utang luar negeri bersih sebesar 25\%, 2) Kenaikan pembiayaan melalui bank sentral sebesar $25 \%$, 3) Kenaikan pembiayaan melalui bank umum sebesar 25\%. Dua: Kebijakan untuk mengurangi defisit anggaran, terdiri dari: 1) Kenaikan tax effort sebesar 25\%, 2) Mengurangi subsidi BBM sebesar 25\%. Tiga: Kebijakan moneter, terdiri dari: Menaikkan cadangan minimum bank umum sebesar 1 poin. Semua variabel kebijakan dispesifikasikan sebagai variabel eksogen kecuali variabel pembiayaan melalui bank umum dispesikasikan sebagai variabel add factors. Tingkat inflasi dan pertumbuhan ekonomi ditentukan sebagai variabel target, sehingga dispesifikasikan sebagai variabel endogen.

Metode simulasi yang digunakan dalam penelitian ini yaitu stochastic simulation dengan menggunakan algoritma extended Newton. Metode simulasi stokastik dipilih karena lebih powerfull dibandingkan metode simulasi deterministik (Pyndick, 1998). Dalam simulasi stokastik setiap replikasi selalu mempertimbangkan error terms yang ada atau lebih tepatnya dalam meramalkan nilai variabel endogen selalu dimulai dengan menciptakan error yang baru dengan tetap mempertahankan nilai koefisien/parameter regresi. Simulasi dilakukan sebanyak 10.000 replikasi (ulangan) dengan interval keyakinan sebesar 95\% (dua sisi).

Langkah pertama dalam proses simulasi adalah menentukan baseline yang merupakan dynamic optimal path dari model yang telah dispesifikasikan. Baseline ditentukan dengan mensolve model regresi ditambah dengan persamaan identitas, tanpa diberikan shock apapun. Hasil yang didapat akan digunakan sebagai dasar untuk melihat pengaruh pemberian suatu shock terhadap variabel endogen. Langkah selanjutnya men-solve model yang telah diberikan shock pada model regresi. Hasil yang didapat akan dibandingkan dengan baseline bukan dengan nilai aktualnya. Nilai simpangan/standar deviasi menunjukkan besarnya pengaruh pemberian suatu shock terhadap variabel endogen.

Uji kemampuan peramalan model dilakukan terhadap kualitas model untuk melakukan peramalan. Kemampuan peramalan suatu model dapat dilihat dari seberapa jauh terjadi perbedaan antara nilai variabel endogen yang sebenarnya menurut observasi dengan nilai variabel endogen menurut perhitungan simulasi dalam periode yang diteliti (ex post simulation). Indikator yang digunakan adalah: 1) Root of Mean Square Error (RMSE), 2) Mean Absolute Error (MAE), 3) Mean Absolute Percent Error (MAPE), 4) Theil Inequality Coefficient (TIC). Indikator RMSE, MAE, dan MAPE merupakan ukuran deviasi antara nilai simulasi dengan nilai aktual. Makin kecil deviasi (yang ditunjukan dengan makin kecilnya nilai indikator), maka akan semakin dekat (berhimpit) antara nilai aktual dengan nilai simulasi. Indikator TIC terletak diantara nilai nol sampai dengan satu, jika mendekati nol menunjukkan ketepatan prediksi dan sebaliknya jika mendekati satu maka nilai simulasi akan jauh dari nilai aktual. Indikator TIC ini juga dilengkapi dengan dekomposisinya, yang terlihat dari nilai-nilai proporsinya (bias, variance, covariance proportion).

\section{HASIL ANALISIS DAN PEMBAHASAN}

Dalam model single equation yang ditaksir dengan SYS TSLS uji statistik model yang digunakan sudah memenuhi semua asumsi Classical Linear Regression Model (CLRM) (Waluyo; 2005). Hasil ini akan memberikan harapan bahwa dalam model simultan yang dispesifikasikan mampu untuk memberikan hasil ramalan yang memuaskan. Pengujian lebih lanjut perlu dilakukan 
untuk melihat kemampuan peramalan model regresi, sehingga nilai ramalan akan mendekati dengan nilai aktual. Kriteria evaluasi yang digunakan yaitu RMSE, MAE, MAPE dan Theil's inequality coefficient, hasil pengujian kemampuan peramalan model dapat dilihat pada tabel 3 .

Uji kemampuan peramalan model (RMSE, MAE, MAPE) pada range data yang tersedia menunjukkan bahwa nilai yang dihasilkan relatif kecil. Hal ini menunjukkan model akan menghasilkan nilai ramalan untuk semua variabel endogen dengan kesalahan rata-rata yang relatif kecil. Kesalahan dalam melakukan peramalan terkecil terlihat pada persamaan fungsi produksi dan nilai tertinggi pada persamaan pembayaran cicilan dan bunga utang luar negeri dan cadangan kredit bank sentral.

Tabel 3

Uji Kemampuan Peramalan Model: Ex-post Simulation

\begin{tabular}{|c|c|c|c|c|c|c|c|}
\hline \multirow{3}{*}{ Persamaan Struktural } & \multirow{3}{*}{ RMSE } & \multirow{3}{*}{ MAE } & \multirow{3}{*}{ MAPE } & \multicolumn{4}{|c|}{ Theil Inequality } \\
\hline & & & & & & Propo & \\
\hline & & & & & Bias & Varian & Covarian \\
\hline 1. Fungsi Produksi & 0.04 & 0.03 & & 0.01 & 0.00 & 0.00 & 0.99 \\
\hline 2. Konsumsi Swasta & 3.62 & 2.38 & 4.49 & 0.03 & 0.06 & 0.03 & 0.91 \\
\hline 3. Investasi Swasta & 2.40 & 1.72 & 9.96 & 0.07 & 0.0 & 0.02 & 0.99 \\
\hline 4.Konsumsi Pemerintah & 0.82 & 0.67 & 448.86 & 0.07 & 0.15 & 0.05 & 0.80 \\
\hline 5. Investasi Pemerintah & 8 & 0.41 & 135.07 & 0.07 & 0.01 & 0.00 & 0.99 \\
\hline 6. Ekspor Minyak & 1.58 & 0.73 & 27.12 & 0.09 & 0.03 & 0.02 & 0.95 \\
\hline 7. Ekspor Non-Migas & 3.60 & 2.61 & 13.98 & 0.06 & 0.00 & 0.02 & 0.98 \\
\hline 8. Impor Barang dan Ja & 3.38 & 2.10 & 10.08 & 0.07 & 0.00 & 0.02 & 0.98 \\
\hline 9. Penerimaan Pajak & 1.54 & 1.29 & 479.88 & 0.09 & 0.10 & 0.02 & 0.88 \\
\hline 10. Penerimaan Minyak dan Gas & 0.9 & 0.57 & 32.61 & 0.11 & 0.00 & 0.02 & 0.98 \\
\hline 11. Pemb. Cicilan dan Bunga ULN & 3.19 & 2.46 & 689.01 & 0.07 & 0.00 & 0.03 & 0.97 \\
\hline 12. Angka Pengganda Uang & 0.12 & 0.09 & 6.44 & 0.04 & 0.01 & 0.02 & 0.97 \\
\hline 13. Cadangan Kredit Bank Sentral & 5.66 & 3.96 & 231.64 & 0.13 & 0.00 & 0.09 & 0.91 \\
\hline 14. Permintaan Uang & 0.06 & 0.04 & 6.05 & 0.03 & 0.00 & 0.01 & 0.98 \\
\hline 15. Suku Bunga Nominal & 0.03 & 0.02 & 16.91 & 0.08 & 0.00 & 0.01 & 0.99 \\
\hline 16. Inflasi & 0.45 & 0.29 & 19.65 & 0.05 & 0.17 & 0.36 & 0.47 \\
\hline 17. Nilai Tukar & 0.67 & 0.51 & 53.19 & 0.08 & 0.01 & 0.02 & 0.97 \\
\hline
\end{tabular}

\section{Sumber: Hasil estimasi regresi}

Theil's Inequality Coefficient (TIC) terletak antara $0.01-0.13$, berarti simpangan antara nilai aktual dengan nilai prediksi sangat kecil. Hasil ini ditunjang pula dengan hasil dekomposisi 
TIC yang menunjukkan bahwa: Nilai proporsi bias menunjukkan bahwa rata-rata (mean) simpangan antara nilai aktual dengan nilai taksiran terletak antara 0.00 (sangat sempurna) sampai dengan 0.17; Nilai proporsi dari Varians terletak antara $0.00-0.36$, berarti varians antara nilai taksiran dengan nilai aktual sangat kecil, kecuali pada persamaan inflasi.; dan Nilai Proporsi covarian menunjukkan bahwa tidak terjadi pengulangan kesalahan yang sistematik dalam model yang digunakan. Hasil TIC secara keseluruhan menunjukkan kualitas peramalan model yang baik, karena nilai bias dan nilai varian yang kecil sehingga kesalahan peramalan akan bertumpu pada covarian-nya.

\subsection{Baseline Skenario}

Tujuan utama membuat baseline skenario untuk melihat dynamic optimal path dari model. Nilai aktual dari data yang ada belum mencerminkan nilai optimal dalam model regresi (Pyndick, 1998). Di samping itu baseline skenario juga menunjukkan nilai dynamic multiplier dari variabel eksogen dalam mempengaruhi variabel endogen. Pada gambar 1 terlihat baseline skenario untuk pertumbuhan ekonomi. Terlihat bahwa pola data sepanjang tahun penelitian adalah relatif sama, sedikit perbedaan mungkin disebabkan oleh penggunaan $A R(2)$. Hal ini menunjukkan bahwa model dapat digunakan untuk melakukan simulasi kebijakan.

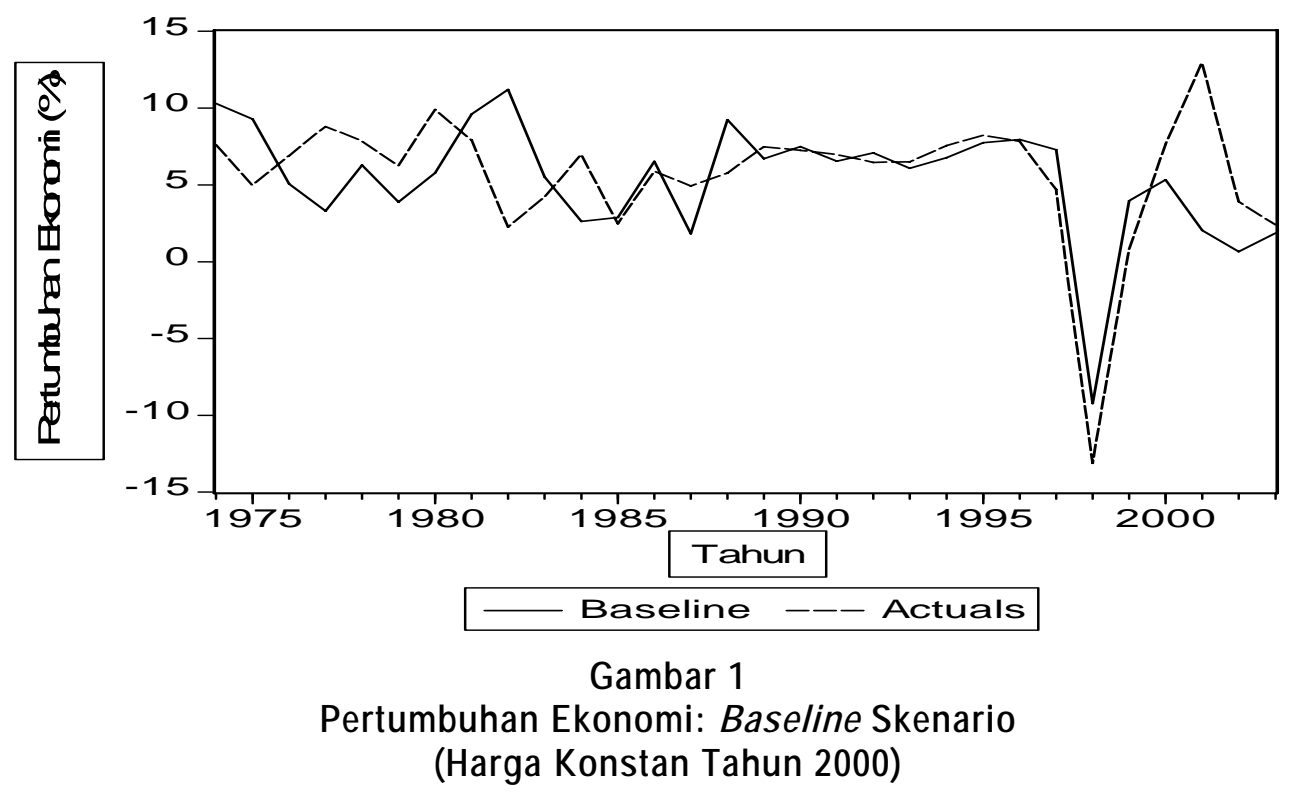

Gambar 2 menunjukkan perbandingan antara baseline dengan nilai aktualnya pada variabel inflasi. Nilai baseline relatif lebih fluktuatif, jika dibandingkan dengan nilai aktual. Pola pergerakan nilai baseline relatif sama dengan nilai aktual. Hal ini mengindikasikan bahwa model bisa digunakan untuk melakukan simulasi kebijakan. Simulasi yang digunakan dalam penelitian ini bersifat baseline neutral, artinya hasil simulasi tidak akan banyak berubah jika baseline diubah kecuali perbedaan baseline dengan nilai aktual relatif besar.

\subsection{Pengaruh Kenaikan Penarikan Utang Luar Negeri Bersih Sebesar 25 Persen}

Utang luar negeri merupakan kebijakan utama yang dijalankan untuk pembiayaan defisit anggaran pemerintah pusat selama tahun penelitian. Dalam analisis ini akan diasumsikan bahwa pemerintah akan membiayai defisit anggaran hanya dengan menggunakan utang luar negeri. Simulasi dilakukan dengan asumsi penarikan utang luar negeri baru meningkat sebesar $25 \%$. Pengaruh kenaikan utang luar negeri terhadap neraca modal sangat tergantung oleh selisih antara besarnya penarikan utang baru dengan pembayaran cicilan pokok utang luar negeri. Pada tahun 2000 neraca modal mengalami kenaikan sebesar 39.8\% sedangkan pada tahun 2003 kenaikan penarikan utang tidak berpengaruh terhadap neraca modal. 


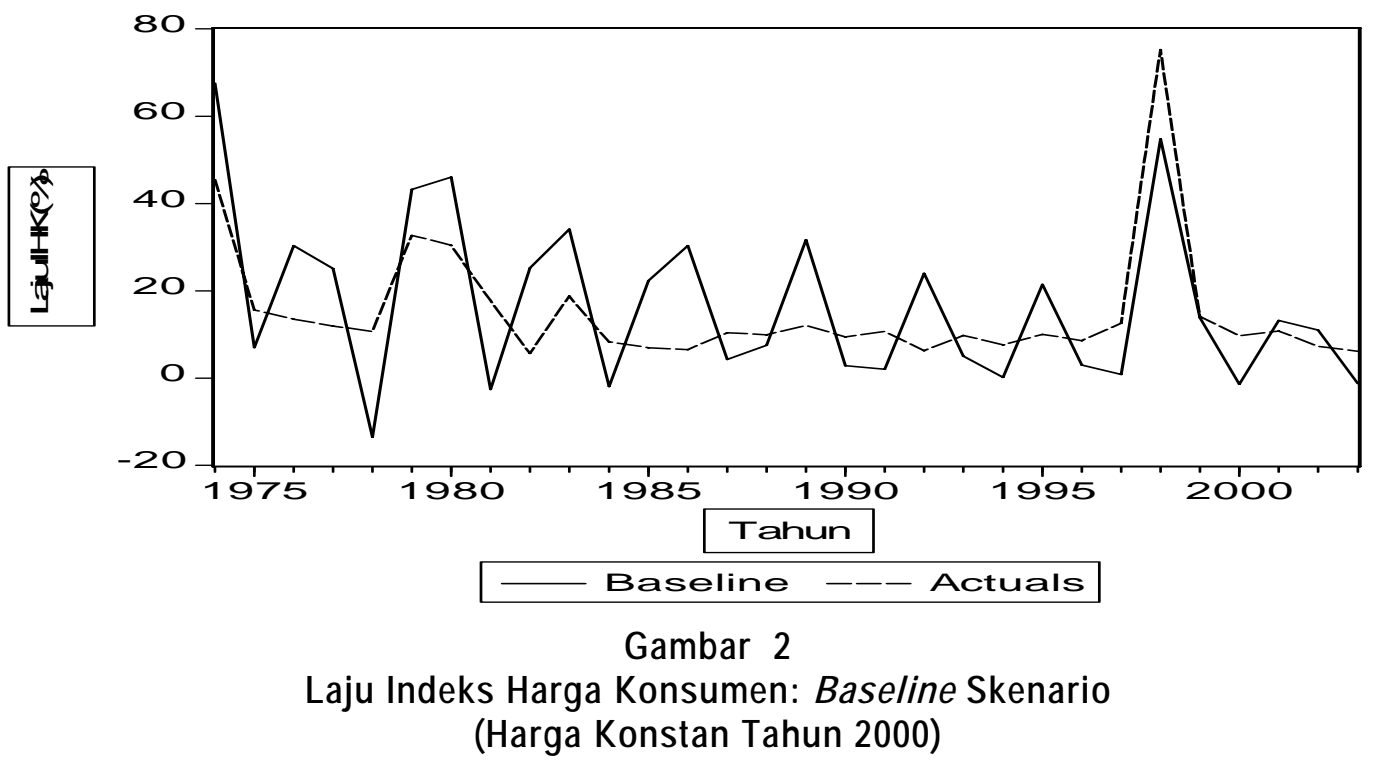

Pengaruh kenaikan utang luar baru selanjutnya, yaitu akan semakin meningkatkan saldo neraca berjalan sebesar $110.00 \%$ pada tahun 2000 dan mengurangi saldo neraca berjalan sebesar $20.9 \%$ pada tahun 2003 . Pengaruh selanjutnya adalah besarnya cadangan devisa yang dihimpun oleh pemerintah, sebesar $174.10 \%$ dan $28.30 \%$ pada tahun 2000 dan 2003. Kenaikan cadangan devisa akan menyebabkan kenaikan pada uang primer sebesar $44.00 \%$ dan $41.00 \%$ pada tahun 2001 dan 2003. Kenaikan uang primer yang terjadi setelah berinteraksi dengan angka pengganda uang maka akan menyebabkan kenaikan pada inflasi, sebesar $8.20 \%$ pada tahun 2000 dan sebesar $7.90 \%$ pada tahun 2003.

Kenaikan neraca modal akan menyebabkan kenaikan pada pengeluaran pemerintah, karena tersedia dana segar dari utang luar negeri. Kenaikan pengeluaran pemerintah akan menyebabkan keleluasaan pada investasi yang harus dilakukan, sehingga investasi pemerintah akan meningkat sebesar $16.30 \%$ pada tahun 2000 dan $15.80 \%$ pada tahun 2003 . Kenaikan investasi pemerintah menyebabkan kenaikan pada pembentukan kapital stok oleh pemerintah, sehingga pada akhirnya akan mempengaruhi perumbuhan ekonomi. 
Tabel 4

Estimasi Pengaruh Kenaikan Penarikan Utang Luar Negeri Baru Sebesar 25\%

\begin{tabular}{lrrrr}
\hline Variabel Endogen & $\mathbf{2 0 0 0}$ & $\mathbf{2 0 0 1}$ & $\mathbf{2 0 0 2}$ & $\mathbf{2 0 0 3}$ \\
\hline & & & & \\
Deviasi terhadap Baseline & & & & \\
Neraca Modal (CPA) & 39.80 & 123.00 & 64.90 & 0.00 \\
Neraca Transaksi Berjalan (CRA) & 110.00 & -15.20 & 58.60 & -20.90 \\
Cadangan Devisa (FR) & 174.10 & 53.90 & 55.60 & 28.30 \\
Pengeluaran Pemerintah (GE) & 11.90 & 12.40 & 20.60 & 15.60 \\
Investasi Pemerintah (IG) & 16.30 & 16.50 & 16.00 & 15.80 \\
Kapital Stok Pemerintah (KG) & 16.00 & 16.10 & 16.10 & 16.00 \\
Pertumbuhan Ekonomi (Q) & 16.50 & 16.80 & 16.00 & 15.40 \\
Uang Primer (MB) & 19.00 & 44.00 & 39.00 & 41.00 \\
Uang Beredar (MS) & 10.60 & 10.80 & 10.90 & 9.40 \\
Defisit Anggaran (DEF) & -34.90 & -46.40 & 207.00 & 18.30 \\
Perubahan Harga (DPD) & 8.20 & 8.00 & 8.20 & 7.90 \\
& & & & \\
\hline \hline
\end{tabular}

Sumber: Simulasi Hasil Estimasi Regresi

\subsection{Pengaruh Kenaikan Pembiayaan Melalui Bank Sentral Sebesar 25 Persen}

Berdasarkan UU RI No. 23 tahun 1999 tentang Bank Indoensia menunjukkan bahwa Bank Indonesia merupakan pemegang kas pemerintah (pasal 52). Fakta ini berimplikasi bahwa pemerintah mempunyai rekening pada bank sentral. Hal ini menunjukkan bahwa neraca otoritas moneter akan berhubungan dengan APBN, yang di APBN dicatat sebagai SAL/SILPA, sedangkan pada neraca otoritas moneter dicatat sebagai net claims on central government (NCG). Dalam simulasi kebijakan variabel NCG bank sentral didefinisikan sebagai add factors. Pada simulasi ini diasumsikan bank sentral akan memberikan kredit kepada pemerintah untuk membiayai defisit APBN (walaupun menurut Undang Undang No.23 Tahun 1999 tidak diijinkan lagi).

Tabel 5 menunjukkan bahwa kenaikan pembiayaan melalui bank sentral akan meningkatkan domestik kredit sebesar $4.00 \%$ pada akhir tahun simulasi. Kenaikan domestik kredit akan meningkatkan uang primer sebesar $27.00 \%$ pada tahun 2000 , dan $26.00 \%$ pada akhir tahun 2003. Kenaikan uang primer akan menyebabkan kenaikan pada penawaran uang (jumlah uang beredar ditangan masyarakat) sebesar $24.41 \%$ pada akhir simulasi. Kenaikan penawaran uang setelah berinteraksi dengan angka pengganda uang akan berpengaruh terhadap kenaikan perubahan tingkat harga sebesar $1.70 \%$ pada tahun 2000 dan $1.60 \%$ pada tahun 2003 . Sedangkan pertumbuhan ekonomi juga akan meningkat sebesar $0.59 \%$ pada akhir tahun simulasi. 
Tabel 5

Estimasi Pengaruh Kenaikan Pembiayaan Melalui Bank Sentral Sebesar 25 Persen

\begin{tabular}{lrrrr}
\hline Variabel Endogen & $\mathbf{2 0 0 0}$ & $\mathbf{2 0 0 1}$ & $\mathbf{2 0 0 2}$ & $\mathbf{2 0 0 3}$ \\
\cline { 1 - 1 } & & & & \\
Deviasi Terhadap Baseline (\%) & & & & \\
\cline { 1 - 5 } Domestik Kredit (DC) & 507.00 & 14.00 & 591.00 & 4.00 \\
Uang Primer (MB) & 27.00 & 2.00 & 26.00 & 26.00 \\
Penawaran Uang (MS) & 35.97 & 319.97 & 197.75 & 24.41 \\
Perubahan Harga (DPD) & 1.70 & 12.80 & 11.60 & 1.60 \\
Pertumbuhan Ekonomi (Q) & 1.15 & 0.65 & 0.42 & 0.59 \\
& & & & \\
\hline \hline
\end{tabular}

Sumber: Simulasi Hasil Estimasi Regresi

\subsection{Pengaruh Kenaikan Pembiayaan Melalui Bank Umum Sebesar 25 Persen}

Hubungan antara pemerintah dengan bank umum tercermin dalam neraca konsolidasi bank umum yang dicatat sebagai NCG. Hasil simulasi terhadap variabel target dapat dilihat pada tabel 6 . Kenaikan NCG pada neraca konsolidasi bank umum akan meningkatkan angka pengganda uang pada tahun 2000, dan menurunkan angka pengganda uang pada akhir tahun simulasi. Kenaikan angka pengganda uang setelah berinteraksi dengan uang primer maka akan mempengaruhi kenaikan penawaran uang. Selama tahun simulasi pengaruh kenaikan pembiayaan melalui bank umum akan meningkatkan inflasi, kecuali pada tahun 2000. Perubahan NCG bank umum selama tahun simulasi berpengaruh meningkatkan pertumbuhan ekonomi.

\subsection{Dampak Kenaikan Tax Effort sebesar 25 Persen}

Pada tabel 7 ditampilkan tiga tahun terakhir dari proses simulasi kebijakan. Kenaikan tax effort (TC) sebesar $25 \%$ akan berdampak meningkatkan penerimaan pajak sebesar $5.40 \%$ pada tahun 2000 dan 22.1\% pada tahun 2003. Kenaikan penerimaan pajak selanjutnya akan meningkatkan penerimaan pajak sebesar $5.50 \%$ pada tahun 2000 dan $20.70 \%$ pada tahun 2003 . Hal ini akan berdampak meningkatkan pengeluaran pemerintah yang tercermin dalam pengeluaran konsumsi dan investasi pemerintah sebesar $13 \%$ dan 35\% pada tahun 2003. Dampak selanjutnya akan mengurangi defisit anggaran pemerintah sebesar $17.40 \%$ dan $26.10 \%$ pada tahun 2002 dan 2003. Kenaikan investasi pemerintah akan meningkatkan pembentukan kapital stok pemerintah sebesar $10.50 \%$ pada tahun 2000 dan $9.70 \%$ pada tahun 2003. Kenaikan kapital stok akan meningkatkan pertumbuhan ekonomi sebesar $3.90 \%$ pada tahun 2000 dan $14.00 \%$ pada tahun 2003. 
Tabel 6

Estimasi Pengaruh Kenaikan Pembiayaan Melalui Bank Umum Sebesar 25 Persen

\begin{tabular}{lrrrr}
\hline Variabel Endogen & $\mathbf{2 0 0 0}$ & $\mathbf{2 0 0 1}$ & $\mathbf{2 0 0 2}$ & $\mathbf{2 0 0 3}$ \\
\hline Deviasi Terhadap Baseline (\%) & & & & \\
\hline Angka Pengganda Uang (MM) & 98.60 & -237.00 & 632.90 & -26.70 \\
Penawaran Uang (MS) & -4.11 & 120.63 & 123.06 & -31.95 \\
Perubahan Harga (DPD) & -0.20 & 12.00 & 10.90 & 0.10 \\
Pertumbuhan Ekonomi (Q) & 1.15 & 0.67 & 0.41 & 0.58
\end{tabular}

Sumber: Simulasi Hasil Estimasi Regresi

Kenaikan pajak juga berpengaruh terhadap pendapatan disposabel masyarakat. Kenaikan tax effort sebesar $25 \%$ akan berdampak terhadap kenaikan pendapatan disposabel sebesar $5.50 \%$ pada tahun 2002 dan $22.00 \%$ pada tahun 2003. Kenaikan pendapatan disposabel secara otomatis akan mempengaruhi kemampuan masyarakat untuk berkonsumsi. Konsumsi masyarakat meningkat sebesar $4.10 \%$ pada tahun 2000 dan sebesar $14.80 \%$ pada tahun 2003 . Hal ini mengindikasikan bahwa kenaikan pajak yang terjadi akan diimbangi oleh kenaikan pendapatan masyarakat. Pendapatan masyarakat naik sebesar $18.10 \%$ pada tahun 2000 dan $15.1 \%$ pada tahun 2003. Hal ini berarti bahwa efektivitas pemungutan pajak yang dilakukan oleh pemerintah tidak berdampak terhadap menurunnya kesejahteraan masyarakat. Fakta ini menunjukkan bahwa kenaikan tingkat pajak masih bisa dilakukan di Indonesia

Kenaikan tax effort tidak berdampak inflationary, hal ini berdasarkan fakta bahwa pada akhir simulasi inflasi akan menurun sebesar $22.00 \%$. Analisis ini diperkuat dengan analisis parsial yang menunjukkan perubahan pendapatan nasional berhubungan positip dan signifikan terhadap perubahan harga. Walaupun pada beberapa tahun terdapat hubungan yang negatip. Hal ini sangat tergantung oleh perubahan pendapatan nasional yang terjadi.

Tabel 7

Estimasi Dampak Peningkatan Tax Effort (TC) sebesar 25 persen

\begin{tabular}{lrrrr}
\hline Variabel Endogen & $\mathbf{2 0 0 0}$ & $\mathbf{2 0 0 1}$ & $\mathbf{2 0 0 2}$ & $\mathbf{2 0 0 3}$ \\
\hline & & & & \\
Deviasi Terhadap Baseline (\%) & & & & \\
\hline Penerimaan Pajak (TX) & 5.40 & 5.40 & 16.20 & 22.10 \\
Penerimaan Pemerintah (GR) & 5.50 & 6.60 & 16.70 & 20.70 \\
Pendapatan Disposabel (YD) & 5.00 & 5.00 & 16.00 & 22.00 \\
Konsumsi Pemerintah (CG) & 4.80 & 5.30 & 9.00 & 13.00 \\
Investasi Pemerintah (IG) & 5.00 & 10.00 & 33.00 & 35.00 \\
Konsumsi Swasta (CP) & 4.10 & 4.60 & 9.30 & 14.80 \\
Pendapatan Nasional (Y) & 18.10 & 17.50 & 13.90 & 15.10 \\
Pengeluaran Pemerintah (GE) & 5.40 & 9.20 & 6.80 & 10.20 \\
Defisit Anggaran (DEF) & 5.10 & 16.10 & -17.40 & -26.10 \\
Kapital Stok Pemerintah (KG) & 10.50 & 9.60 & 9.40 & 9.70 \\
Pertumbuhan Ekonomi (Q) & 3.90 & 5.00 & 9.40 & 14.00 \\
Perubahan Harga (DPD) & 8.00 & 8.00 & 9.00 & -22.00 \\
\hline
\end{tabular}

Sumber: Simulasi Hasil Estimasi Regresi 


\subsection{Dampak Penurunan Pengeluaran untuk Subsidi BBM Sebesar 25 Persen}

Pengurangan subsidi sebesar $25 \%$ akan mengurangi transfer ke masyarakat sebesar $2.20 \%$ pada tahun 2000 dan $25.00 \%$ pada tahun 2003, tetapi mengalami kenaikan pada tahun 2001 sebesar $40.60 \%$ (tabel 8). Hal ini sangat tergantung oleh perubahan beban pembayaran bunga dan cicilan utang luar negeri (DSCF). Jika DSCF berubah sama dengan atau lebih kecil daripada perubahan penurunan subsidi yang dilakukan maka akan berpengaruh negatip terhadap transfer yang terjadi.

Tabel 8

Estimasi Dampak Pengurangan Subsidi BBM Sebesar 25 persen

\begin{tabular}{lrrrr}
\hline \multicolumn{1}{c}{ Variabel Endogen } & $\mathbf{2 0 0 0}$ & $\mathbf{2 0 0 1}$ & $\mathbf{2 0 0 2}$ & $\mathbf{2 0 0 3}$ \\
\hline & & & & \\
Deviasi terhadap Baseline (\%) & & & & \\
\hline Transfer (TR) & -2.20 & 40.60 & -39.60 & -25.00 \\
Pengeluaran Pemerintah (GE) & -3.60 & 71.80 & -64.00 & -129.30 \\
Defisit Anggaran (DEF) & -6.10 & 53.20 & -39.80 & 9.70 \\
Pertumbuhan Ekonomi (Q) & 0.20 & 1.50 & 29.40 & 89.30 \\
Perubahan Harga (DPD) & 0.00 & 0.00 & 0.00 & 0.00 \\
Pembayaran Bunga Utang (DSCF) & 12.30 & 9.40 & -117.50 & 410.90 \\
& & & & \\
\hline
\end{tabular}

Sumber: Simulasi Hasil Estimasi Regresi

Besarnya transfer yang terjadi akan mengurangi pengeluaran pemerintah sebesar $3.60 \%$ pada tahun 2000 dan $129.30 \%$ pada tahun 2003. Dampak selanjutnya akan mengurangi defisit anggaran yang terjadi. Pengurangan defisit anggaran akan berdampak terhadap meningkatnya pembayaran beban bunga dan cicilan pokok utang luar negeri. Hal ini mengindikasikan bahwa pengurangan subsidi yang dilakukan, sebagian dananya akan digunakan untuk melakukan pembayaran utang. Pengurangan subsidi sebesar $25 \%$ akan berdampak terhadap kenaikan pertumbuhan ekonomi sebesar $0.20 \%$ pada tahun 2000 dan $89.30 \%$ pada akhir simulasi. Pengurangan subsidi berdampak netral terhadap perubahan harga.

\subsection{Kebijakan Moneter: Kenaikan Cadangan Minimum (Reserve Requirement) Bank Umum sebesar 1 poin}

Salah satu kebijakan moneter yang dapat dielaborasi lebih lanjut dalam model yang dispesifikasikan adalah dengan meningkatkan cadangan minimum bank umum (RR). Tabel 9 menunjukkan hasil estimasi dampak kenaikan RR sebesar 1 poin. Kenaikan RR akan berdampak meningkatkan RBC sebesar $19.75 \%$ pada tahun 2003, selanjutnya akan berdampak meningkatkan domestik kredit (DC) sebesar $40.00 \%$ pada tahun 2003. Kenaikan domestik kredit akan meningkatkan uang primer sebesar $25.00 \%$ pada akhir simulasi. Pada sisi yang lain kenaikan RR akan meningkatkan angka pengganda uang sebesar $5.00 \%$ pada akhir simulasi. Interaksi antara uang primer dengan angka pengganda uang akan berdampak mengurangi penawaran uang sebesar $-6.15 \%$ pada akhir simulasi. Penurunan penawaran uang akan berdampak mengurangi inflasi sebesar $0.40 \%$ pada akhir tahun 2003. Sedangkan tingkat pertumbuhan ekonomi riil mengalami kenaikan sebesar $0.57 \%$ pada akhir tahun simulasi. 
Tabel 9

Estimasi Dampak Kenaikan Cadangan MinimumBank Umum Sebesar 1 Poin

\begin{tabular}{lrrrr}
\hline Variabel Endogen & 2000 & 2001 & 2002 & 2003 \\
\hline Deviasi Terhadap Baseline (\%) & & & & \\
& & & & \\
Angka Pengganda Uang (MM) & 842.94 & -429.66 & 449.73 & 5.10 \\
Cadangan Kredit Bank Sentral (RBC) & -20.46 & 37.18 & 183.51 & 19.75 \\
Domestik Kredit (DC) & 89.00 & -60.00 & -491.00 & 40.00 \\
Uang Primer (MB) & -24.00 & -4.00 & 31.00 & 25.00 \\
Penawaran Uang (MS) & -33.60 & 261.63 & 179.93 & -6.15 \\
Perubahan Harga (DPD) & -0.70 & 12.40 & 11.10 & -0.40 \\
Pertumbuhan Ekonomi (Q) & 1.16 & 0.65 & 0.41 & 0.57
\end{tabular}

Sumber: Simulasi Hasil Estimasi Regresi

\subsection{Beberapa Implikasi Kebijakan}

Pada bagian ini akan dicoba menyusun policy ranking dari seluruh skenario yang telah dijalankan. Ranking kebijakan ini akan disusun berdasarkan kriteria sebagai berikut: 1) Berdampak paling besar terhadap pertumbuhan ekonomi, 2) Berdampak paling kecil terhadap inflasi, dan 3) Memberikan dampak penurunan defisit anggaran yang paling besar. Hasilnya dapat dilihat pada tabel 10 .

Tabel 10

Perbandingan Beberapa Skenario

\begin{tabular}{lrrrrrr}
\hline \multicolumn{1}{c}{ Variabel Endogen } & \multicolumn{7}{c}{ Akhir Simulasi } \\
\multicolumn{1}{c}{ Target } & $\begin{array}{r}\text { GDF } \\
(+25 \%)\end{array}$ & $\begin{array}{r}\text { GDCB } \\
(+25 \%)\end{array}$ & $\begin{array}{r}\text { GDNCB } \\
(+25 \%)\end{array}$ & $\begin{array}{c}\text { TC } \\
(+25 \%)\end{array}$ & $\begin{array}{c}\text { SUB } \\
(-25 \%)\end{array}$ & $\begin{array}{r}\text { RR } \\
(+1)\end{array}$ \\
\hline & & & & & & \\
Pertumbuhan Ekonomi (Q) & 15.40 & 0.59 & 0.58 & 14.00 & 89.30 & 0.57 \\
Perubahan Tingkat Harga (DPD) & 7.90 & 1.60 & 0.10 & -22.00 & 0.00 & -0.40 \\
Defisit Anggaran (DEF) & 18.30 & - & - & -26.10 & 9.70 & - \\
& & & & & & \\
\hline
\end{tabular}

Urutan kebijakan sesuai dengan policy ranking yang disusun dapat dilihat pada tabel 11. Berdasarkan kriteria pertama maka urutan ranking kebijakan sebagai berikut: 1) Mengurangi Subsidi BBM, 2) Penarikan utang luar negeri baru, 3) Menaikkan tax effort, 4) Menaikkan pembiayaan melalui bank sentral, 5) Menaikkan pembiayaan melalui bank umum, dan 6) Menaikkan cadangan minimum bank umum. Berdasarkan kriteria kedua urutan ranking kebijakan sebagai berikut: 1) Menaikkan tax effort, 2) Menaikkan cadangan minimum bank umum, 3) Mengurangi Subsidi BBM, 4) Menaikkan pembiayaan melalui bank umum, 5) Menaikkan pembiayaan melalui bank umum, dan 6) Penarikan utang luar negeri baru. Berdasarkan kriteria ketiga urutan ranking kebijakan sebagai berikut: 1) Menaikkan tax effort, 2) Mengurangi Subsidi $\mathrm{BBM}, 3)$ Penarikan utang luar negeri baru. 
Tabel 11

Policy Ranking Simulasi Kebijakan

\begin{tabular}{lcccc}
\hline \multicolumn{1}{c}{ Variabel Kebijakan } & Kriteria & Akhir \\
& I & II & III & \\
\hline 1. Penarikan Utang Luar Negeri Baru & 2 & 6 & 3 & 3 \\
2. Menaikkan Pembiayaan Melalui Bank Sentral & 4 & 5 & - & 6 \\
3. Menaikkan Pembiayaan Melalui Bank Umum & 5 & 4 & - & 5 \\
4. Menaikkan Tax Effort & 3 & 1 & 1 & 1 \\
5. Mengurangi Subsidi BBM & 1 & 3 & 2 & 2 \\
6. Menaikkan Reserve Requirement & 6 & 2 & - & 4 \\
& & & & \\
\hline
\end{tabular}

Berdasarkan assesment di atas terlihat bahwa kebijakan dengan menaikkan tax effort merupakan kebijakan yang paling baik, kemudian diikuti oleh kebijakan mengurangi subsidi, sedangkan utang ke luar negeri, melalui sektor perbankan merupakan kebijakan yang bersifat inflationary. Fakta ini didukung pula dengan masih rendahnya rasio penerimaan pajak terhadap PDB di Indonesia, yaitu sekitar $5.33 \%-13.63 \%$ atau dengan rata-rata baru mencapai $9.45 \%$. Hal ini mengindikasikan bahwa pemerintah masih mempunyai keleluasaan untuk meningkatkan penerimaan pajaknya.

Pengurangan subsidi BBM merupakan kebijakan yang mampu meningkatkan pertumbuhan ekonomi dan tidak bersifat inflationary. Di samping itu penghematan BBM akan mengurangi polusi, dan sangat ramah lingkungan. Pengurangan subsidi juga akan "mendidik" masyarakat untuk lebih bijaksana dalam menggunakan energi yang bersifat non renewable resources. Permasalahan pengurangan subsidi akan muncul jika dikaitkan dengan permasalahan politik, yang menyangkut keadilan.

Pembiayaan dengan menggunakan utang luar negeri harus sangat hati-hati dijalankan, karena beban utang pemerintah sudah sangat besar. Sejak krisis ekonomi utang luar negeri Indonesia meningkat sangat drastis dari 6.60\% terhadap PDB pada tahun 1998 menjadi $111.75 \%$ terhadap PDB. Tetapi kecenderungannya rasio utang pemerintah terhadap PDB semakin menurun. Hal ini merupakan dampak kebijakan fiskal berhati-hati yang dijalankan oleh pemerintah. Kebijakan utang luar negeri pemerintah harus ditempuh dengan tujuan utama untuk mengurangi ketergantungan terhadap utang luar negeri, sehingga suatu saat jumlah utang luar negeri sangat sedikit atau bahkan nol.

\section{SIMPULAN}

Berdasarkan hasil analisis dan pembahasan dapat disimpulkan bahwa: Pembiayaan defisit anggaran dengan menggunakan utang luar negeri, melalui bank sentral, dan melalui bank umum akan berdampak meningkatkan pertumbuhan ekonomi dan bersifat inflationary. Secara umum kebijakan menaikkan tax effort dan mengurangi subsidi BBM merupakan kebijakan yang paling baik, karena dapat meningkatkan pertumbuhan ekonomi, dan relatif tidak bersifat inflationary. Pembiayaan dengan menggunakan utang luar negeri harus berhati-hati, karena stok utang luar negeri Indonesia sangat besar, sehinga rawan terhadap fluktuasi nilai tukar, dan bersifat inflationary. Kebijakan moneter dengan menaikkan cadangan minimum bank umum sangat efektif untuk mengurangi tingkat inflasi.

Model yang digunakan dalam penelitian ini memiliki beberapa keterbatasan anatara lain: Pertama: Model yang dikembangkan bersifat model statik, sehingga analisis yang dilakukan terbatas pada statik komparatif. Kedua: Model yang dikembangkan belum memasukan pasar 
tenaga kerja, sehingga dampak perilaku pasar tenaga kerja dalam mempengaruhi inflasi dan pertumbuhan ekonomi belum terekam dengan baik.

\section{DAFTAR PUSTAKA}

Blejer, Mario I, dan Cheasty, Adriene, (1991), "The Measurement Fiscal Deficits: Analytical and Methodological Issues", Journal of Economic Literatur, Desember 1991, Vol. XXIX.

Blejer, Mario I, dan Cheasty, Adriene, (1992), "How to Measure the Fiscal Deficit", Finance and Development, September 1992, 29 (3): 40-42.

Booth, Anne dan McCawley, Peter, (1996), "Kebijakan Fiskal", dalam Anne Booth dan Peter McCawley, eds., Ekonomi Orde Baru, LP3ES, Jakarta, Februari1996.

Buiter, Willem H., (1982), "The Proper Measurement of Government Budget Deficits: Comprehensive Wealth Accounting or Permanent Income Accounting for the Public Sector: Its Implications for Policy Evaluation and Design" NBER (Cambridge, MA) Working Paper No. 1013, http://www.nber/papers/w1013.pdf

Buiter, Willem H., (1995), "Measuring Fiscal Sustainability", Mimeo European Bank for Reconstruction and Development.

Chantrasmi, Mary, (1990), "Government Budget Deficit, Crowding-Out and Inflation in Thailand 1970 - 1986", Ph.D Dissertation, University of Hawaii.

Choeryanto, Syaifoel, (2000), Model Ekonomi Makro Indonesia, Lembaga Penerbit Fakultas Ekonomi Universitas Indonesia

Elmendorf, Douglas W dan Mankiw, N. Gregory, (1998), "Government Debt." National Bureau of Economic Research (Cambridge, MA) Working Paper No. 6470, Maret 1998. http://www.nber.org/papers/w6470.pdf

Gunardi, Harry Seldadyo, (2000), "Defisit APBN dan Fiscal Sustainability: Suatu Studi Tentang Ekonomi Indonesia 1983/1984-1999/2000", Penelitian Program Magister IImu Ekonomi, Universitas Indonesia, Jakarta (tidak dipublikasikan).

Gunawan, Anton Hermanto, (1991), Anggaran Pemerintah dan Inflasi di Indonesia, Jakarta:Penerbit PT Gramedia Pustaka Utama, Jakarta.

Hossain, Akhtar dan Chowdry, Anis, (1998), Open-Economy Macroeconomics for Developing Countries, Cheltenham: Edward Elgar.

Internasional Monetary Fund, (2004), "International Finance Statistics CD Room." Agustus 2004.

International Monetary Fund, (Berbagai Tahun Penerbitan), "Government Finance Statistics Yearbook.", Washington DC: IMF. 
Joseph, Charles PR, Arief Hartawan, dan Firman Mochtar, (1999), "Kondisi dan Respon Kebijakan Ekonomi Makro Selama Krisis Ekonomi Tahun 1997-1998”, Buletin Ekonomi dan Moneter Bank Indonesia, Vol.2 No.2, September 1999.

Pyndick, Robert S, dan Daniel L Rubinfeld, (1998), Econometric Models and Economic Forecasts, 4PthP. Singapore: McGraw-Hill Book Co.

Saleh, Ali Salman, (2003), "The Budget Deficit and Economic Performance: A Survey", Economics Working Paper Series, University of Wollongong, Toronto: Harcourt Brace Jovanovich, September 2003.

Saleh, Ali Salman, (2004), "Public Sector Deficits and Macroeconomics Performance in Lebanon", Ph.D Dissertation, University of Wollongong Australia.

Seda, Frans, (2004), "Kebijakan Anggaran Penerimaan dan Belanja Negara (APBN) Berimbang dan Dinamis", dalam Heru Subiyantoro dan Singgih Riphat, eds, Kebijakan Fiskal, Penerbit Buku Kompas.

Scarth, William M, (1996), Macroeconomics: An Introduction to Advance Methods, Toronto: Harcourt Brace Jovanovich.

Soelistyo, Aris dan Mansur, Farid Wijaya, (1998), "Suatu Pendekatan Ekonometri Terhadap Ekonomi Makro Indonesia (1978-1994)", Jurnal Ekonomi dan Bisnis Indonesia.

Tokunaga, Suminori, (1997), "A Quarterly Macro Econometric Model for Indonesian Economy", dalam Dorodjatun Kuntjoro-Jakti, Komara Jaya, Ari Kuncoro, Syahgena Ardhila, Eds, Macroeconomics Modelling in Developing Countries: With Special Reference to Indonesia, LPEM FE-UI, September 1997.

Turnovsky, Stephen J dan Wohar, Mark E., (1987), "Alternative Modes of Deficit Financing and Endegenous Monetary and Fiscal Policy 1923 - 1982", National Bureau of Economic Research Working Paper No. 2123 (Cambridge, MA), Januari 1987.

Waluyo, Joko, (2005), "Implikasi Pembiayaan Defisit Anggaran Pemerintah Pusat Terhadap Inflasi dan Pertumbuhan Ekonomi: Studi Kasus Indonesia 1970 - 2003", Penelitian Program Magister IImu Ekonomi Universitas Indonesia, Depok, Agustus 2005 (Tidak dipublikasikan).

Wicaksono, Gunawan dan Ariantoro, Eko, (2003), "Pengujian Validitas Data Stok Kapital dan Perkembangan Stok Kapital Indonesia." Buletin Ekonomi Moneter dan Perbankan, Bank Indonesia Desember 2003, 6 (3).

Wicaksono, Gunawan dan Ariantoro, Eko, dan Sari, A. Rheina, (2002), "Penghitungan Data Stok Kapital Dengan Metode Perpetual Inventory (PIM): Suatu Upaya Penyediaan Data Stok Kapital Untuk Penghitungan Potensial Output Dengan Pendekatan Fungsi Produksi", Buletin Ekonomi Moneter dan Perbankan, Bank Indonesia, September 2002, 5 (2).

World Bank, (2000), "Indonesia: Managing Government Debt and Its Risks", East Asia and the Pasific Region, Washington DC: The Worldbank, Mei 2000. 
KINERJA, Volume 10, No.1, Th. 2006: Hal. 1-22

Yudanto, Noor, Gunawan Wicaksono, Eko Ariantoro, dan A Rheina Sari, (2004), "Capital Stock in Indonesia: Measurement and Validity Test", Irving Fisher Committe (IFC) Conference, Basel, 9 -10 September 2004. 